др Ана Јаковљевић-Радуновић

др Ана Голубовић

Универзитет у Београду

Филолошки факултет

Катедра за славистику

anajakovljevic@yahoo.com
УДК 012 Сибиновић М. https://doi.org/10.18485/slavistika.2021.25.1.3 Библиографија примљено 15.05.2021. прихваћено за штампу 17.06.2021.

\title{
БИБЛИОГРАФИЈА ПРОФ. ДР МИОДРАГА СИБИНОВИЋА
}

селективна библиографија научних монографија, приређених издања, научних радова у периодици, зборницима и у издањима дела страних писаца у преводу на српски језик и превода

\section{Монографске публикације}

1. Љермонтов у српској књижевности : до другог светског рата. - Београд : Филолошки факултет, 1971. - 227 стр. - (Монографије ; 39)

2. Оригинал и превод : увод у историју и теорију превођења. - Београд : Привредна штампа, 1979. - 191 стр.

3. „Evgenije Onjegin” Aleksandra Puškina. - Beograd : Zavod za udžbenike i nastavna sredstva, 1982. - 105 str. - (Biblioteka Portret književnog dela)

4. O prevođenju : priručnik za prevodioce i inokorespondente. - Beograd : Zavod za udžbenike i nastavna sredstva, 1983. - 112 str.

5. Поетика и поезија : велики руски лиричари. - Београд : Књижевна заједница Звездара, 1990. - 202 стр. - (Библиотека Монографије, студије, критике ;1)

6. Нови оригинал : увод у превођење. - Београд : Научна књига, 1990. - 193 стр.

7. Техника превођења : уџбеник за III и IV разред културолошко-језичке струке : општи део. - Београд : Завод за уџбенике и наставна средства, 1990. -98 стр.

8. Словенски импулси у српској књижевности и култури : славистичка студија 1. - Београд : Филолошки факултет : Књижевна заједница Звездара, 1995. - 254 стр. - (Библиотека Монографије, студије, есеји, критике ; 11)

9. Руски песници од барока до авангарде. - Београд : Завод за уџбенике и наставна средства, 1995. - 237 стр.

10. Између светова : нови аспекти књижевног дела Десанке Максимовић. Београд : Задужбина Десанке Максимовић : Народна библиотека Србије : Просветни преглед, 1999. - 218 стр. - (Студије о књижевном делу Десанке Максимовић ; 4)

11. Пушкинов и српски Евгеније Оњегин : поводом двестагодишњице Пушкиновог рођења. - Београд : Идеа, 1999. - 190 стр. - (Библиотека Расветљења ; 6)

12. Руски књижевни источници : Пушкин, Љермонтов, Јесењин, Мандељштам, 
Ахматова, Платонов. - Ниш : Просвета, 2000. - 176 стр.

13. Иза хоризонта : огледи из руске, украјинске, белоруске и грузијске књижевности. - Београд : Чигоја штампа, 2002. - 174 стр.

14. Нови живот оригинала : увод у превођење. - Београд : Просвета : Алтера : Удружење научних и стручних преводилаца, 2009. - 309 стр. - (Едиција Приручници ; 1)

15. Словенска вертикала : српске, руске, белоруске и украјинске књижевне теме. - Београд : Славистичко друштво Србије, 2008. - 434 стр. - (Славистичка библиотека ; 7)

16. Индивидуална конкретизација књижевног дела : студије о руској и српској књижевности. - Београд : Филолошки факултет, 2012. - 467 стр.

17. Славистичке теме : чланци и студије. - Београд : Филолошки факултет, 2015. - 268 стр. - (Едиција Језик, књижевност, култура ; 5)

18. Množenje svetova : ruski pisci u srpskoj prevodnoj književnosti. - Beograd : Clio, 2015. - 218 str. - (Agora)

19. Кроз гриву зене : рашчитавање песама о коњу из поезије словенских народа. - Београд : Филолошки факултет Универзитета, 2017. - 164 стр. (Библиотека Посебно издање)

\section{Приређена издања}

1. Сабрана дела I-V / C. Јесењин ; [као члан Редакционог одбора, заједно са Н. Бертолином и М. Живанчевићем]. - Београд : Народна књига, 1966.

2. Бездани огледала / Н. Заболоцки. - Београд : Култура, 1968.

3. Изабрана дела / М. Љермонтов. - Београд : Просвета, 1968.

4. Гвоздени сан / М. Љермонтов. - Београд : Култура, 1969.

5. Целокупна дела I-VI / С. Јесењин ; [као члан Редакционог одбора, заједно са Н. Бертолином и М. Живанчевићем]. - Београд : Рад, 1970.

(Издање је поновљено 1971, 1973, 1975, 1980, 1985).

6. Лирика / Б. Пастернак. - Београд : Рад, 1972.

7. Песме / Е. Јевтушенко ; [у коауторству са М. Бабовићем]. - Београд : Рад, 1973.

8. Прстен живота / А. Блок. - Београд : БИГЗ, 1975.

9. Песме / В. Мајаковски, С. Јесењин, Е. Јевтушенко. - Београд : Нолит :

Просвета : Завод за уџбенике и наставна средства, 1978.

10. Сабрана дела у три књиге / М. Љермонтов. - Београд : Рад, 1980.

11. Песме / А. Блок. - Београд : Рад, 1982.

12. Песме и поеме / В. Мајаковски. - Београд : Рад, 1983.

13. Витез у тигровој кожи / Ш. Руставели. - Београд : СКЗ, 1989.

14. Поезија / С. Јесењин. - Никшић : Унирекс, 1995.

15. Јунак нашег доба / М. Љермонтов. - Подгорица : Унирекс : Завод за уџбенике 
и наставна средства, 1996.

16. Евгеније Оњегин. Цигани / А. С. Пушкин. - Подгорица : Унирекс : Завод за уџбенике и наставна средства, 1997.

17. Александар Солжењицин : уметник, мислилац, пророк / Жорж Нива. Београд : Ново дело, 1999.

18. Бронзани коњаник. Пир за време куге. Световна власт / А. Пушкин. Београд : Ideia, 1999.

19. Два века Пушкина : песме и бајке. - Београд : Interpres, 1999.

20. Песме, поеме и есеји / А. Ахматова. - Београд : Рaideia, 1999.

21. Песме и есеји / Осип Мандељштам. - Београд : Просвета, 1999.

22. Руски песници о љубави : Баћушков, Давидов, Пушкин, Веневитинов, Баратински, Љермонтов, Кољцов, Њекрасов, Тјутчев, Павлова, Полонски, Фет, Хипијус, Ањенски, Брјусов, Блок, Мајаковски, Хлебњиков, Јесењин, Гумиљов, Ахматова, Пастернак, Цветајева, Мандељштам, Заболоцки, Бродски. - Београд : Паидеиа, 1999.

23. Сабрана дела 1-5 / С. Јесењин ; [са Н. Бертолином и М. Живанчевићем]. Beograd : VERZALpress, 2000.

24. Руске ноћи / В. Одојевски. - Београд : Паидеиа, 2001.

25. Тужни демон : песме / М. Љермонтов. - Београд : Просветни преглед, 2001.

26. Песме / В. Кордун. - Градишка : Српско просвјетно и културно друштво Просвјета ; Бања Лука : Друштво српско-украјинског пријатељства Републике Српске, 2003.

27. Приповетке / А. Пушкин.- Београд : Портал, 2003.

28. Смешне и страшне приче / Николај В. Гогољ. - Београд : Портал, 2003.

29. Хумореске и приче / А. Чехов. - Београд : Портал, 2003.

30. Видовито срце : руске народне песме и мисли. - Београд : Народна књига, 2004.

31. Под заклетвом : приче и изводи из писама / А. Чехов. - Београд : Паидеиа, 2004.

32. Левак : предање о тулском разроком леваку и челичној буви / Николај Љесков. - Београд : Интерпрес, 2005.

33. Антологија руске лирике X-XXI век, том 1-3. - Београд : Паидеиа, 2007.

34. Лирика / А. Кушнер. - Смедерево : Међународни фестивал поезије Смедеревска песничка јесен, 2007.

35. Одабрана проза : приче и исписи / Николај Гогољ. - Београд : Завод за уџбенике, 2010.

36. Песме и поеме / Александар Блок. - Нови Сад : Orpheus, 2010.

37. Песме и поеме / Михаил Љермонтов. - Нови Сад : Orpheus, 2010.

38. Изабране песме / Ана Ахматова. - Нови Сад : Orpheus, 2011.

30. Изабране песме / Николај Заболоцки. - Нови Сад : Orpheus, 2011.

40. Целокупна дела, том VIII и IX, Преводи / Десанка Максимовић. - Београд : 
Службени гласник : Завод за уџбенике, 2012.

41. Венац за Мандељштама : поезија, проза, есеји, преписка : руски и српски писци о Мандељштаму / приредио и предговор написао Миодраг Сибиновић. - Нови Сад; Сремски Карловци : Издавачка књижарница Зорана Стојановића, 2019.

\section{Научни радови објављени у периодици, колективним зборницима и у издањима дела страних писаца у преводу на српски језик}

1. Различити токови једног живота : Шолоховљев проседе у двема књигама „Узоране ледине” // Стремљења. - Год. III, бр. 6 (1962), стр. 741-747.

2. Андреј Вознесенски и нова совјетска поезија // Гледишта. - Год. IV, бр.9-10 (1963), стр. 66-72.

4. Дискусија о настави књижевности на универзитетима у Совјетском Савезу // Гледишта. - Год. V, бр. 5 (1964), стр. 653-655.

5. Искривљена истина о Сергеју Јесењину // Гледишта. - Год. VI, бр. 2 (1965), стр. 269-271.

6. Белешке о Јесењиновим песмама // Сабрана дела I-V / С. Јесењин. - Београд : Култура, 1966. - Књ. I, стр. 367-407; књ. II, стр. 259-299; књ. III, стр. 235-259.

7. Библиографија превода Јесењинових дела у југословнсим листовима и часописима // Сабрана дела I-V / С. Јесењин. - Београд : Култура, 1966. - Књ.V, стр. 297-305.

8. Елеменат конфликта и мелодија Јесењинове песничке слике у преводима на српскохрватски језик // Зборник радова о превођењу. - Београд : Савез књижевних преводилаца Југославије, 1966. - Стр. 28-39.

9. Ко је убио Љермонтова? // Књижевне новине. - Бр. 277 (1966), стр. 10.

10. Песници и белетристи у совјетској поезији 1965. године // Књижевне новине. - Бр. 274 (1966), стр. 4.

11. Поезија је и средство превођења // Књижевне новине. - Бр. 277 (1966), стр. 10.

12. Све сами реакционар // Књижевне новине. - Бр. 285 (1966), стр. 9-10.

13. Сергеј Јесењин: 1. Песников животни пут; 2. Јесењин и народно стваралаштво; 3. Јесењинова песничка слика; 4. Јесењин и његово дело на српскохрватском језичком подручју : предговор // Сабрана дела I-V / C. Јесењин. - Београд : Култура, 1966. - Књ. I, стр. 367-407.

14. Сергеј Јесењин „Бреза”// Књижевне новине. - Бр. 272 (1966), стр. 4.

15. Змајев Демон // Књижевна историја. - Бр. 1 (1968), стр. 69-105.

16. Против догми : о поезији Николаја Заболоцког : предговор // Бездани огледала : песме и поеме / Николај Заболоцки. - Београд : Култура, 1968. Стр. VII-XX.

17. Љермонтов: 1814-1841. : предговор // Демон / М. Љермонтов. - Београд : Рад, 1969. - Стр. 69-72. 
18. Љермонтовљево дело у стваралаштву српских песника XIX века // Књижевна историја. - Бр. 7 (1969), стр. 69-137.

19. Пут кременит : о лирици М. Љермонтова : предговор // Гвоздени сан / М. Љермонтов. - Београд : Култура, 1969. - Стр. VII-XXIII.

20. Јесењиново песничко дело // Целокупна дела I-VI / C. Јесењин. - Београд : Рад, 1970. - Књ. VI, стр. 153-200.

21. Оркестрација и ритмичка структура у Јесењиновој поезији // Зборник Матице српске за славистику. - Бр. 1 (1970), стр. 27-36.

22. Лирика Бориса Пастернака : предговор // Лирика / Б. Пастернак. - Београд : Рад, 1972. - Стр. 9-33.

23. Белински у оценама југословенских књижевних историчара и критичара после Другог светског рата // Наслеђе естетичке и књижевно-критичке мисли Белинског. - Београд : Међународни славистички центар СР Србије, 1975. - Стр. 141-146.

24. Коментари о превођењу лирских песама А. Блока // Прстен живота / А. Блок. - Београд : БИГ3, 1975. - Стр. 301-325.

25. О књижевном преводу прозе : један од могућих аспеката // Мостови. - Бр. 23 (1975), стр. 97-103.

26. Од беспућа до распућа : о поезији Александра Блока : предговор // Прстен живота / А. Блок. - Београд : БИГЗ, 1975. - Стр. 7- 40.

27. Приступ преводу песме // Мостови. - Бр. 22 (1975), стр. 97-108.

28. Књижевни превод и време // Књижевна реч. - Бр. 7 (1976), стр. 7.

29. „Летопис Матице српске” и руска књижевност до 1848. // Научни састанак слависта у Вукове дане. - Бр. 5 (1976), стр. 432-438.

30. Први преводи из руске поезије у „Летопису Матице српске” // Мостови. Бр. 28, св. 4 (1976), стр. 289-296.

31. Романтизам у руској књижевности : Русија на прелому између XVIII и XIX века; Отаџбински рат 1812. и идејна струјања у Русији током прве половине XIX века; Романтизам и његов развој у руској књижевности прве половине XIX века; Романтизам као књижевни правац у тумачењу руске и совјетске науке о књижевности у односу на друга тумачења; В. А. Жуковски; К. Н. Баћушков; Песници декабристи; Прожимање праваца; И. А. Крилов; А. С. Грибоједов; А. С. Пушкин; М. Ј. Љермонтов // Руска књижевност, књ. 1 / М. Стојнић, М. Мулић, М. Милидраговић, М. Сибиновић, Д. Недељковић. - Сарајево : Свјетлост ; Београд : Нолит, 1976. - Стр. 161-294.

32. Књижевни превод и преводилац // Мостови. - Бр. 32, св. 4 (1977), стр. 297-306.

33. Из истории поэтического перевода в Югославии // Мастерство перевода. Москва, 1977. - Стр. 208-230.

34. Из опыта исследования поэтики Есенина // Сергей Есенин : проблемы творчества. -Москва, 1978. - Стр. 245-254.

35. Лингвистичка и књижевна концепција превођења // Руковет. - Бр. 3-4 (1978), стр. 165-171. 
36. Мајаковски, Јесењин и Јевтушенко : поговор // Песме / В. Мајаковски, С. Јесењин, Е. Јевтушенко. - Београд : Нолит : Просвета : Завод за уџбенике и наставна средства, 1978. - Стр. 149-152.

37. Мостови преко којих нема ко да прође : за критику преводне књижевности // Књижевне новине. - Бр. 573 (1978), стр. 171.

38. Роман Максима Горког „Мати” // Мати / Максим Горки. - Београд : Рад, 1978. - Стр. 7-19.

39. Руска поезија средином века : Ф. И. Тјутчев; Н. А. Њекрасов; А. А. Фет // Руска књижевност, књ. 2 / М. Стојнић, Д. Недељковић, М. Сибиновић, Д. Перовић, М. Милидраговић, М. Бабовић, С. Пенчић, М. Јовановић.Сарајево : Свјетлост ; Београд : Нолит, 1978. - Стр. 47-96.

40. Актуелна идејно-политичка питања употребе српскохрватског језика : прилог дискусији // Српскохрватски језик : актуелна питања. - Београд : Рад, 1979. - Стр. 65-68.

41. За критику преводне књижевности // Преводна књижевност. - Београд : Удружење књижевних преводилаца Србије, 1980. - Стр. 166-169.

(Прештампано из Књижевних новина)

42. Књижевно дело М. Ј. Љермонтова : предговор // Сабрана дела / М. J. Љермонтов. - Београд : Рад, 1980. - Књ. 1, стр. 5-55.

43. Коментари уз преводе Љермонтовљевих дела : Љермонтовљеве лирске песме; Љермонтовљеве поеме; Љермонтовљеве драме; Писма; Љермонтовљева проза // Сабрана дела / М. Ј. Љермонтов. - Београд : Рад, 1980. - Књ. 1, стр. 457-487; књ. 2, стр. 401-412; књ. 3, стр. 361-371.

44. Превођење песничког текста // Знак. - Бр. 12 (1980), стр. 42-46.

45. Aktuàlni problèmy výchovy překladatelu // Acta Universitatis Carolinae : Philologika : Slavica Pragensia (Praha). - Br. XXIV(1981), str. 215-221.

46. Зелени огањ Сергеја Јесењина : предговор // Песме / С. Јесењин. - Београд : Рад, 1981. - Стр. 5-17.

47. Приручна литература за наставу страних језика у светлу потреба нашег реформисаног система образовања // Приручна литература у настави страних језика. - Београд : Завод зауџбенике и наставна средства, 1981. - Стр. 63-67.

48. Ствараоци и теоретичари // Теорија и поетика превођења. - Београд : Просвета 1981. - Стр. 27-43.

49. Теорија превођења и књижевни жанрови : разговор у редакцији // Књижевне новине. - Бр. 638 (1981), стр. 6.

50. Змајева елегија „Пођем, клецнем, идем, застајавам” // Књижевна историја. Бр. 55 (1982), стр. 343-354.

51. Институционално образовање преводилаца у светлу Резолуције о самоуправном преображају вишег и високог школства // Преводилац. Бр. 1, св. 3 (1982), стр. 1-6.

52. О вредновању превода лирске песме : на примеру превода Љубомира Симовића песме Ј. Баратинског „Натпис” // Међај. - Бр. 4 (1982), стр. 43-51. 
53. О преводилачким жанровима у односу према књижевним // Мостови. - Бр. 50 (1982), стр. 69-74.

54. О узајамном односу преводилачких и књижевних жанрова са становишта теорије превођења // Научни састанак слависта у Вукове дане. - Бр. 12, св. 3 (1982), стр. 13-19.

55. „Тајна рођења” Растка Петровића // Књижевна историја. - Бр. 56 (1982), стр. 549-570.

56. Универзалност поезије Александра Блока : предговор // Песме / А. Блок. Београд : Рад, 1982. - Стр. 5-14.

57. Уџбеници и приручници за преводилачка усмерења у средњем образовању // Живи језици. - Бр. 24, св. 3-4 (1982), стр. 18-29.

58. Актуелни проблеми образовања преводилаца у СФРЈ // Преводилац. - Бр. 2, св. 3 (1983), стр. 5-17.

59. Доситеј Обрадовић као преводилац // Преводилачке споне : зборник радова. - Нови Сад : Институт за јужнословенске језике Филозофског факултета, 1983. - Стр. 17-25.

60. Један могући конспект за преглед савремене југословенске теоријске мисли о превођењу // Преводилац. - Бр. 2, св. 3 (1983), стр. 5-17.

61. Песник Владимир Мајаковски : предговор // Песме и поеме / В. Мајаковски. - Београд : Рад, 1983. - Стр. 5-17.

62. Змајев стих у преводима из руске поезије // Змајев стих. - Нови Сад : ВАНУ, 1985. - Стр.131-140.

63. О вредновању превода лирске песме // О преводима из руске књижевности : преводилачка читанка / П. Пипер. - Нови Сад : Филозофски факултет, 1985. - Стр. 181-190.

64. Уметничке особине Домановићеве „Данге” // Књижевна историја. - Бр. 6970 (1985), стр. 119-129.

65. Кошутићев допринос развоју наше теоријске мисли о превођењу // Радован Кошутић и развој југословенске славистике. - Београд : Савез славистичких друштава СР Србије, 1986. - Стр. 63-67. - (Славистички зборник ; књ. 1)

66. Проблем заједничких уџбеника у СФРЈ // Преводилац. - Бр. 5, св. 3 (1986), стр. 5-8.

67. L'approche de la traduction de la poésie // Мостови. - Бр. 70 (1987), стр. 177-187.

68. Нивои еквивалентности у књижевном преводу // Научни састанак слависта у Вукове дане. - Бр. 16, св. 3 (1987), стр. 301-307.

69. Верзије превода // Преводилац. - Бр. 7, св. 2 (1988), стр. 15-20.

70. Dosadašnja iskustva i problemi u radu s obdarenima // Uspostavljanje sistema rada sa talentovanom decom i omladinom. - Beograd : Republički zavod za unapređenje vaspitanja i obrazovanja, 1988. - Str. 15-24.

71. Књижевни превод као књижевно дело : на материјалу Винаверовог превода Блокове поеме „Дванаесторица” // Književno prevođenje : teorija i istorija 
: zbornik radova. - Beograd : Institut za književnost i umetnost ; Požarevac : Braničevo ; Novi Sad : Književna zajednica Novog Sada, 1989. - Стр. 25-30.

72. Место књижевног превода у науци о превођењу : разговор у редакцији, учесници: Светозар М. Игњачевић, Мирослава Спасић, Јован Јанићијевић, Ранко Бугарски, Љубиша Рајић, Владимир Ивир, Миодраг Сибиновић, Еуген Вербер // Мостови. - Бр. 2 (1989), стр.189-217.

73. Објашњења : коментари уз превод Руставелијевог „Витеза” // Витез у тигровој кожи / Ш. Руставели. - Београд : СКЗ, 1989. - Стр. 279-291.

74. Первые сербские переводы русской поэзии XVIII века // Русско-сербские литературные связи XVIII - начала XIX века. - Москва : Наука ; Нови Сад : Матица српска, 1989. - Стр. 25-42.

75. Песништво је од памтивека врста мудрости било : Руставелијев „Витез у тигровој кожи" : предговор // Витез у тигровој кожи / Ш. Руставели. Београд : СКЗ, 1989. - Стр. VII-XXXVII.

76. Винаверов приступ оригиналу у превођењу Блокове поеме „Дванаесторица” // Призма. - Бр. 1 (1990), стр. 124-135.

77. Округли сто о књизи Саве Бабића „Како смо преводили Петефија” : учесници Марија Циндори, Бранимир Човић, Лаза Ћурчић, Андраш Давид, Мирослав Дудок, Владислава Фелбабов, Томислав Кетиг, Меланија Микеш, Петар Милосављевић, Миодраг Сибиновић // Руковет. - Бр. 4 (1990), стр. 1264-1296.

78. Доситејева концепција превођења и српска књижевност // Научни састанак слависта у Вукове дане. - Бр. 19, св. 2 (1991), стр. 301-307.

79. Изгнанство у поетици романтизма // Научни састанак слависта у Вукове дане. - Бр. 20, св. 1 (1991), стр. 113-121.

80. Ликови и сижејне линије као уланчани мотиви у Винаверовом преводу Блокове „Дванаесторице” // Упоредна истраживања 3. - Београд : Институт за књижевност и уметност, 1991. - Стр. 377-385.

81. Национално и универзално у средњошколској настави књижевности : на грађи која се односи на место руске књижевности у општеобразовним средњошколским наставним програмима // Живи језици. - Бр. 33, св. 1-4 (1991), стр. 7-19.

82. Превод са превода посредника // Преводилац. - Бр. 3-4 (1991), стр. 38-41.

83. Пушкин, Љермонтов и бајронизам у српској књижевности XIX века // Bajron i bajronizam u jugoslovenskim književnostima. - Beograd : Institut za književnost i umetnost ; Zagreb : Zavod za znanost o književnosti Filozofskog fakulteta ; Požarevac : Centar za kulturu, 1991. - Стр. 101-109.

84. Конвергентан и дивергентан развој словенских са западноевропским културама // Савремник плус. - Бр. 2 (1992), стр. 86-89.

85. Љермонтов данас // Савременик плус. - Бр. 1 (1992), стр. 48-56.

86. Његош и поетика превода Вуковог доба // Анали Филолошког факултета. Бр. ХIX (1992), стр. 441-454.

87. Откривање Гумиљова : поводом додељивања награде „Милош Ђурић” 
Владимиру Јагличићу за превод поезије Николаја Гумиљова // Политика. - Бр. 28440 (1992), стр. 15.

88. Творческое в художественном переводе как части литературного процесса // Литература и перевод : проблемы теории. - Москва, 1992. - Стр. 233243.

89. Бела музика белоруске поезије : поглед на белоруску поезију од њених почетака до данашњих дана : поговор // Антологија белоруске поезије / приредио И. Чарота. - Београд : СКЗ : Научна књига, 1993. - Стр. 173-191.

90. Белая музыка беларускай паэзіі : превод скраћене верзије поговора из Антологије белоруске поезије (Београд, 1993) // Голас Радзімы (Мінск). Бр. 21 (1993), стр. 1,5,7.

91. Varijabilita překladu literárního tekstu // Acta Universitatis Carolinae : Translatorica Pragensia (Praha). - Бр. V (1993), стр. 183-189.

92. Допринос Б. Миљковића и С. Раичковића рецепцији Мандељштамове поезије у српској књижевности // Књижевна историја. - Бр. 91 (1993), стр. 349-358.

93. Заједничка традиција или универзалност људске природе : украјинскосрпске књижевне везе // Српски књижевни гласник. - Бр. 7-8 (1993), стр. 33-34.

94. Однос аутохтоног књижевног процеса и преводне књижевности : на материјалу рецепције руске модерне поезије у српској књижевности ХX века // Прилози проучавању српско-руских књижевних веза. - Нови Сад : Матица српска, 1993. - Стр. 23-36.

95. Руска емиграција у српској култури // Политика, културни додатак. - Бр. 2 (1993), стр. 16.

96. Руски авангардни песник Александар Веденски // Српски књижевни гласник. - Бр. 2 (1993), стр. 94-97.

97. Славянская общность и место поэзии русского модернизма в сербской литературе середины XX века // XI. medzinarodny zjazd slavistov. Bratislava : Vydavatel'stvo Slovenskej akadémie vied, 1993. - Стр. 585-586.

98. Словенска узајамност у другој половини XX века // Савременик плус. - Бр. 9, св. 11 (1993), стр. 3-8.

99. У инат ветровима : уз нове преводе из савремене украјинске поезије, осврт на српско-украјинске везе у XVIII, XIX и XX веку // Савременик плус. - Бр. 3-4 (1993), стр. 431-437. 100. Актуелни задаци савремене југословенске књижевне компаратистике // Летопис Матице српске. - Бр. 453 (1994), стр. 483-494.

101. Грузијска дојава Отара Чиладзеа // Летопис Матице српске. - Св. 3 (1994), стр. 313-332.

102. Канвергентнае ці дывергентнае развіццё культур славянскіх адносна заходнееўрапейскіх // Культура (Мінск). - Бр. 52 (1994), стр. 10.

103. Научные чтения, посвященные русской эмиграции в Югославии // Славяноведение (Москва). - Бр. 3 (1994), стр. 126-127. 
104. Перспективе савремене славистике // Зборник Матице српске за славистику. - Бр. 46-47 (1994), стр. 7-17.

105. Поетика и семантика песме „Движение” Николаја Заболоцког // Зборник Матице српске за књижевност и језик. - Бр. XLII, св. 1-3 (1994), стр. 431-437.

106. Руска емиграција у српској култури $\mathrm{XX}$ века : оквири и перспективе истраживања // Руска емиграција у српској култури XX века, том I. Београд : Филолошки факултет, 1994. - Стр. 5-21.

107. Славянская общность и место поэзии русского модернизма в сербской литературе середины ХХ века // Славяноведение (Москва). - Бр. 5 (1994), стр. 87-90.108. Грузијска дојава Отара Чиладзеа : поговор // И ко год ме сретне / О. Чиладзе. - Београд : СК3, 1995. - Стр. 443-459.

109. Из преводилачке радионице : из јерменске поезије // Књижевне новине. Бр. 915 (1995), стр. 4.

110. Из преводилачке радионице : Осип Мандељштам „Лењинград”// Књижевне новине. - Бр. 913 (1. септембар1995), стр. 4.

111. Из преводилачке радионице : Сергеј Јесењин „Јесен” // Књижевне новине. - Бр. 914 (1995), стр. 4.

112. Магија Јесењинове поезије : предговор // Поезија / С. Јесењин. - Никшић : Унирекс ; Подгорица : Народна библиотека Радослав Љумовић ; Београд : Књижевне новине-комерц,1995. - Стр. V-XLIII.

113. Максим Рыльский и сербская литература // М. Рильський і світова культура 3 погляду сучасности : міжнародна конференція. - Київ : Національна академія наук України, 1995. - Стр. 61.

114. Некоторые актуальные вопросы современной славистики // Вестник Московского университета, сер. Филология (Москва). - Бр. 6 (1995), стр. 21-30.

115. Песников век : плави звек потковице Јесењиновог Пегаза : поговор // Плавет века / С. Јесењин. - Београд : Interpress, 1995. - Стр. 96-99.

(2. изд. 2011.)

116. Актуални проблеми изучавања Јесењиновог живота и дела // Зборник Матице српске за славистику. - Бр. 50-51 (1996), стр. 9-15.

117. Значение русской эмиграции в сербской культуре XX века : границы и перспективы исследования // Русская эмиграция в Югославии. - Москва : Индрик, 1996. - Стр. 7-26.

118. Једна душа на размеђи светова : Јесењиново дело на крају XX века // Савременик плус. - Бр. 38-39-40 (1996), стр. 24-27.

119. Љермонтовљев роман „Јунак нашег доба” : поговор // Јунак нашег доба / М. Љермонтов. - Подгорица : Унирекс, 1996. - Стр. 160-169.

120. Нацыянальнае, рэгіянальнае и еўропейскае як элементы літературнага працэсу : на матерыяле беларускай, сербскай, харвацкай, украінскай і рускай літератур // Кантакты і дыалогі (Мінск). - Бр. 5 (1996), стр. 15-17.

121. Наши руски песници : век и по од Љермонтовљеве смрти // Словенске 
културе и историја међусловенских веза : зборник радова. - Београд : Друштво српско-руског пријатељства, 1996. - Стр. 41-54.

122. Раичковићеви преводи из поезија словенских // Поезија Стевана Раичковића : зборник радова. - Београд : Задужбина Десанке Максимовић, 1996. Стр. 127-134.

123. Сећања на послератног доајена српске полонистике професора Ђорђа Живановића // Сто година полонистике у Србији : зборник радова. - Београд : Филолошки факултет, Славистичко друштво Србије, 1996. - Стр. 57-61.

124. Методологические проблемы исследования российской эмиграции 20 века в области культурологии, литературоведения и языкознания // IV международный симпозиум Международной ассоциации преподавателей русского языка и литературы : сопоставительные и сравнительные исследования русского и других языков : доклады. - Белград : Славистическое общество Сербии, 1997. - Стр. 38-44.

125. Один погляд на сербсько-українські взаємини // Слов'янський світ (Київ). - Бр. 1 (1997), стр. 110-115.

126. Поэтика Есенина между модернизмом и авангардизмом // Столетие Сергея Есенина : международный симпозиум. - Москва : Наследие, 1997. - Стр. 185-190. - (Есенинский сборник ; вып. III)

127. Проблеми објављивања превода уЦелокупним делима Десанке Максимовић // Приређивање Целокупних дела Десанке Максимовић : зборник радова. - Београд : Задужбина Десанке Максимовић, 1997. - Стр. 77-84.

128. Радован Лалић и послератна српска русистичка књижевна компаратистика // Славистичка истраживања Радована Лалића. - Београд : Српски лексикограф ; Никшић : Филозофски факултет, 1997. - Стр. 47-53.

129. Речь по поводу присуждения ученого звания почетного доктора Московского государственного университета им. М. В. Ломоносова // Вестник Московского университета : Серия 9, Филология. - Бр. 4 (1997), стр. 232234.

130. Руска емиграција у српској култури XX века : о савременим истраживањима места руске емиграције у српској и југословенској култури XX века // Зборник Матице српске за славистику. - Бр. 53 (1997), стр. 235-254.

131. Српска култура и књижевност у европском контексту : кратко образложење и подаци о Пројекту који финансира Министарство за науку и технологију Републике Србије // Славистика. - Бр. I (1997), стр. 121-122.

132. Десанка Максимовић и Ана Ахматова // Новине Београдског читалишта. Бр. 27 (1998), стр.13.

133. Десанка Максимовић и свет // Књижевност. - Бр. 5-6 (1998), стр. 911-928.

134. Песнички преводи Десанке Максимовић // Десанка Максимовић : споменица о 100-годишњици рођења. - Ваљево, 1998. - Стр. 464-475.

135. Пушкинова поема „Цигани” и његов роман „Евгеније Оњегин” : поговор // Евгеније Оњегин. Цигани / А. С. Пушкин. - Подгорица : Унирекс, 1998. - Стр. 209-250. 
136. Рецепција јужнословенске поезије у преводима Десанке Максимовић // Балканите. Ние сред другите и те сред нас : юбилеен сборник в чест на 70-годишнината на проф. Илия Конев, доктор на филологическите науки. - София : Международен университетски семинар за балканистични проучвания и специализации при ЮЗУ Неофит Рилски,1998. - Стр. 345-356.

(Исти текст у: Рецепција дела Десанке Максимовић : зборник радова. - Београд : Задужбина Десанке Максимовић, 1998. - Стр. 33-48)

137. Уметничка логика апсурда : „Тјутењ, Витјутењ и Протегален” А. Платонова // Sprache und Erzahlhaltung bei Andrej Platonov / Herausgegeben von Robert Hodel und Jan Peter Locher. - Bern ; Berlin ; Frankfurt a. M. ; New York ; Paris ; Wien, 1998. - Str. 343-356.- (Slavica Helvetica ; vol. 58)

138. Актуелна књига о Солжењицину која је потребна и српском читаоцу // Александар Солжењицин : уметник, мислилац и пророк / Жорж Нива. Београд : Ново дело, 1999. - Стр. 172-173.

139. Живот и дело Осипа Мандељштама // Песме и есеји / Осип Мандељштам. - Београд : Просвета, 1999. - Стр. 5-45.

140. Једна загонетка из оставштине Драгутина Илића у Архиву САНУ // Зборник Матице српске за књижевност и језик. - Бр. XLVII, св. 2-3(1999), стр. 445-447.

141. Коментари // Два века Пушкина : песме и бајке. - Београд : Интерпрес, 1999. - Стр.257-279.

142. Коментари // Песме и есеји / Осип Мандељштам. - Београд : Просвета, 1999. - Стр. 257-283.

143. Коментари // Песме, поеме и есеји / А. Ахматова. - Београд : Паидеиа, 1999. - Стр. 257-292.

144. Лично и универзално : бесједа о Пушкину // Овдје. - Бр. 370-371-372 (1999), стр. 142-143.

145. Наш савременик Александар Пушкин : предговор // Бронзани коњаник. Пир за време куге. Световна власт / А. Пушкин. - Београд : Ideia, 1999. Стр. 7-14.

146. Поезија Ане Ахматове : предговор // Песме, поеме и есеји / А. Ахматова. Београд : Паидеиа, 1999. - Стр. 5-30.

147. Пушкин и његова лирска поезија : предговор // Два века Пушкина : песме и бајке. - Београд : Интерпрес, 1999. - Стр. 7-28.

148. Пушкин и српска култура // Задужбина. - Бр. 46 (1999), стр. 5.

149. Пушкин неумрли // Prevodilac. - Бр. 18, св. 3-4 (1999), стр. 23-37.

150. Десанка Максимовић и свет // Дело Десанке Максимовић у токовима српске и светске књижевности. - Београд : Задужбина Десанка Максимовић, 2000. - Стр. 5-28.

151. Коментари // Сабрана дела 1-5 / С. Јесењин. - Београд : VERZALpress, 2000. - Књ. 1, стр. 239-264; књ. 2, 251-275; књ. 3, 267-278.

152. Сергеј Јесењин на крају века : предговор // Сабрана дела 1-5 / С. Јесењин. 
- Београд : VERZALpress, 2000. - Књ. 1, стр.7-45.

153. Хронологија живота Сергеја Јесењина // Сабрана дела 1-5 / С. Јесењин. Београд : VERZALpress, 2000. - Књ. 5, стр. 313-320.

154. Видови и облици креације у књижевном преводу // Преводна књижевност. Београд : Удружење књижевних преводилаца Србије, 2001. - Стр. 20-25.

155. Poezija filozofije i slovenska utopija Vladimira Odojevskog : predgovor// Ruske noći / Vladimir Odojevski. - Beograd : Paideia, 2001. - Str. 5-12.

156. Српска преводна и оригинална књижевност и Вуково доба // Преводна књижевност. - Београд : Удружење књижевних преводилаца Србије, 2001. - Стр. 209-267.

157. Хоризонти // Градина. - Бр. 9, св. 12 (2001), стр. 208-210.

158. Александар Пушкин и његов роман „Евгеније Оњегин” : предговор // Александар Пушкин / Евгеније Оњегин. - Београд : Завод за уџбенике и наставна средства, 2002. - Стр. 7-35.

159. Избор из критике о Пушкину. Хронолошка таблица Пушкиновог живота и дела. Основна литература о Пушкину на нашем језику : избор // Александар Пушкин / Евгеније Оњегин. - Београд : Завод за уџбенике и наставна средства, 2002. - Стр. 221-240.

160. Коментари : О Пушкиновим поемама и лирским песмама // Цигани. Бронзани коњаник. Лирске песме. - Београд : Завод за уџбенике и наставна средства, 2002. - Стр. 179-211.

161. О поеми „Цигани”, о „Бронзаном коњанику” и о лирици Александра Пушкина // Цигани. Бронзани коњаник. Лирске песме. - Београд : Завод за уџбенике и наставна средства, 2002. - Стр. 7-32.

162. Словенска поезија у књижевној породици Илић // Радови. - Бр. 5 (2002), стр. 85-104.

163. У инат ветровима : кратак осврт на узајамну историју српско-украјинских књижевних и културних веза до почетка 20. века // У инат ветровима : антологија украјинске поезије : XVI-XX век. - Бања Лука ; Српско Сарајево : Друштво српско-украјинског пријатељства републике Српске : Завод за уџбенике и наставна средства Републике Српске, 2002. - Стр. $617-639$.

164. Хронолошка таблица Пушкиновог живота и дела // Цигани. Бронзани коњаник. Лирске песме. - Београд : Завод за уџбенике и наставна средства, 2002. - Стр. 225-234.

165. Гогољев смех кроз сузе туге и ганућа : поговор // Смешне и страшне приче / Н. В. Гогољ. - Београд : Портал, 2003. - Стр. 171-179.

166. Позија Виктора Кордуна : предговор // Песме / Виктор Кордун. - Градишка : Српско просвјетно и културно друштво Просвјета ; Бања Лука : Друштво српско-украјинског пријатељства Републике Српске, 2003. - Стр. 3-15.

167. Пушкин и његове приповетке : поговор // Пикова дама. Белкинове и друге приповетке / А. С. Пушкин. - Београд : Портал, 2003. - Стр. 107-112.

168. Светски класик Антон Чехов : поговор // Хумореске и приповетке / А. П. 
Чехов. - Београд : Портал, 2003. - Стр. 164-172.

169. Улога породице Илић у српској рецепцији словенске поезије // Породица Илић у српској књижевности. - Београд : Институт за књижевност и уметност, 2003. - Стр. 51-66.

170. Антон Чехов после једног века : предговор // Под заклетвом : приче и изводи из писама / А. Чехов. - Београд : А. Чехов, 2004. - Стр. 5-22.

(Скраћена верзија у: Књижевни магазин. - Бр. 35, 36 (2004), стр. 19-23, 26-27)

171. Једном руком чвор се не везује : поговор // Видовито срце : руске народне песме и мисли. - Београд : Народна књига : Алфа, 2004. - Стр. 141-153.

172. Неуништива Љесковљева бува : предговор // Левак / Николај Љесков. Београд : Интерпрес, 2005. - Стр. 5-7.

173. Превод и постмодерна // Политика, култура-уметност-наука. - Бр. 7 (2005), стр. 7.

174. Преводилаштво као изазов : и срећа и недоумица // Политика, културауметност-наука. - Бр. 25 (2005), 8.

175. Жигосане песме и њихови творци или стрељане илузије // Развитак. - Бр. 225/226 (2006), стр. 34-35.

176. Конвергенція чи дивергенція слов'янських і західноєвропейських культур // Слов’янський світ. - Бр. 4 (2006), стр. 3-7.

177. Песник Александар Кушнер // Лирика / А. Кушнер. - Смедерево : Међународни фестивал поезије Смедеревска песничка јесен, 2007. - Стр. $186-213$.

178. Приступ преводу постмодернистичке прозе : одломак из књиге „Нови живот оригинала" // Преводилац. - Бр. 26, св. 1/2 (2007), стр. 37-51.

179. Проћи живот није поље прећи : поводом поенте Пастернакове песме „Хамлет”, пронађене у руској народној изреци // Вечерње новости, додатак Култура (18. април 2007), стр. III.

180. Сиже наде Риме Казакове // Вечерње новости, додатак Култура (21. фебруapa 2007), стр. III.

181. Уводне напомене о антологији // Антологија руске лирике : X-XXI век. Београд : Паидеиа, 2007. - Књ. I, стр. 5-7.

182. Живи поетски текст // Књижевне новине. - Бр. 1149 (2008), стр. 8.

183. Змајева елегија „Пођем, клецнем, идем, застајавам” // Романтизам и реализам у српској и европској књижевности : есеји, књижевнотеоријски, књижевнокритички, књижевноисторијски, аналитички радови и библиографија. - Нови Сад : Змај, 2008. - Стр. 177-185.

184. Песме Давида Зиљберштејна : поговор // Поезија / Д. Зиљберштејн. Београд : Прометеј, 2008. - Стр. 211-217.

185. Попуњавање празнина у име хармоничног развоја наше културе // Бестселер. - Бр. 62 (2008), стр. 3.

186. Књижевноисторијски значај Глишићевих превода Н. В. Гогоља // Књиженост. - Бр. 1 (2009), стр. 80-91. 
187. О књижевноисторијском значају Глишићевих превода Н. В. Гогоља // Глишић и Домановић / уредник Светлана Велмар-Јанковић. - Београд : САНУ, 2009. - Стр. 253-264. - (Научни скупови ; књ. 123. Одељење језика и књижевности ; књ. 19)

188. Два века Николаја Гогоља // Одабрана проза : приче и исписи / Николај Гогољ. - Београд : Завод за уџбенике, 2010. - Стр. 7-14.

189. Песме и поеме Александра Блока : предговор // Песме и поеме / Александар Блок. - Нови Сад : Orpheus, 2010. - Cтр. III-LVI.

190. Поезија Михаила Љермонтова : предговор // Изабране песме / М. Љермонтов. - Нови Сад : Орфеус, 2010. - Стр. III-LVI.

191. Јесењинова поетична проза // Јаруга : песникова проза / С. А. Јесењин. Власотинце : Народна библиотека Десанка Максимовић, 2011. - Стр. 7-8.

192. Медаљони о књижевности // Буктиња. - Бр. 30 (2011), стр. 49-61.

193. Поезија Ане Ахматове : предговор // Изабране песме / А. Ахматова. - Нови Сад : Орфеус, 2011. - Стр. III-XXVI.

194. Поезија Николаја Заболоцког : предговор // Изабране песме / Н. Заболоцки. - Нови Сад : Орфеус, 2011. - Стр. III-XXV.

195. Напомене // Целокупна дела, књ. VIII и IX, Преводи / Десанка Максимовић. - Београд : Службени гласник : Завод за уџбенике, 2012. - Стр. 521-581; стр. 917-1020;

196. Превод и култура данас // Prevodilac. - Год. 31, бр. 3/4 (2012), стр. 15-24.

197. Прилог разговору о теми поезија и музика // Буктиња. - Бр. 34 (2012), стр. 63-94.

198. Уметничке особине Домановићеве „Данге” // Буктиња. - Бр. 31 (2012), стр. 29-38.

200. Струны пявучыя душы беларускай : слова на прэзентацыі кнігі „Антологија белоруске поезије", 13 чэрвеня 2012 г., Белград, Нацыянальная бібліятэка Сербіi // Полымя (Мінск). - Бр. 6 (2013), стр. 168-175.

201. Наш Љермонтов : поводом двестагодишњице рођења Љермонтова : предговор // Два века Љермонтова : одабране песме и слике. - Београд : Интерпрес, 2014. - Стр. 5-21.

202. Неман времена у поезији Томислава Мијовића : поговор // Дах и прах / T. Мијовић. - Београд : Књижевно друштво Свети Сава, 2014. - Стр. 83-97.

203. Црни таласи // Буктиња. - Бр. 42 (2014), стр. 5-15.

204. Пожар из пожара // Мой Есенин. - Београд : Интерпрес, 2015. - Стр. 56-69. 205. Богатство другости светова // Ризница. - Бр. 1 (2016), стр. 86-100.

206. Десанка Максимовић у песничкој интерпретацији Ане Ахматове // Српска књижевност 20. века : поетика превођења и интеркултурно истраживање : упоредна истраживања 5. - Београд : Институт за књижевност и уметност, 2016. - Стр. 161-181. - (Годишњак ; 22. Сер. А, Компаративна изучавања српске књижевности ; 5)

207. О књизи „Тако и јесте” и песнику Андреју Базилевском : поговор // Тако и 
јесте / А. Базилевски. Београд : Интерпрес, 2016. - Стр. 115-119.

208. Песме Дмитрија Бикова // Савременик плус. - Бр. 249-250-251 (2016), стр. $17-19$.

209. Место украјинске књижевности у српској науци о књижевности и култури // Украјинистика и словенски свет : зборник научних радова : поводом 25 година украјинистике на Универзитету у Београду / гл. ур. Људмила Поповић. - Београд : Филолошки факултет, 2017. - Стр. 45-62.

210. Пламен у балканској ноћи // Знаци из нутрине / Зоран Вучић. - Неготин : Књижевно-издавачко друштво Лексика, 2017. - Стр. 44-55.

211. Недосегнути или погажени хоризонти // Кремен и сени : поема о Мандељштаму / Вукашин Костић. - Београд : Интерпрес, 2018. - Стр. $109-122$.

212. Осип Мандељштам у српском руху и духу : рецепција Мандељштама у српској књижевности и култури // Славистика. - Бр. ХХІІ, св. 1 (2018), стр. 193-262.

213. Петар Митропан, истакнути српски русист, филолог и преводилац // Српскоруски круг : књижевно-уметнички алманах = Сербско-русский круг : литературно-художественный альманах : 2018/2019 / ур. Андреј Базилевски. Москва : Вахазар ; Београд : Интерпрес, 2018. - Стр. 338-347.

214. Бранко Миљковић у српској рецепцији поезије Валерија Брјусова // Славистика. - Бр. XXIII, св. 1 (2019), стр. 189-200.

215. Мандељштам у српском руху и духу // Венац за Мандељштама : поезија, проза, есеји, преписка : руски и српски писци о Мандељштаму / приредио и предговор написао Миодраг Сибиновић. - Нови Сад ; Сремски Карловци : Издавачка књижарница Зорана Стојановића, 2019. - Стр. 325-465.

216. Непролазни Јесењин // Ко сам, шта сам : изабране песме и поеме / Сергеј Јесењин ; избор Миодраг Чолаковић. - Београд : Ленто, 2019. - Стр. 5-42.

\section{Хроника и Personalia}

1. С пјесмом у вјечност : уз седамдесетогодишњицу рођења Мајаковског // Крајина. - Бр. 231 (1963), стр. 5.

2. Доживљавање чуда : поводом додељивања Андреју Вознесенском награде „Златни венац” Струшких вечери поезије // Политика (14. Априла 1984).

3. Дубоки Дон : човекова судбина : поводом смрти Михаила Шолохова // НИН (26. фебруара 1984).

4. Извештај о расправи о „Нацрту програма рационализације мреже и капацитета вишег и високог школства Скупштине СР Србије" : ставови са појединих већа факултета и института сродних наука // Билтен Универзитета у Београду. - Бр. 1 (1984), стр. 22-25.

5. Нацрт Закона о усмереном образовању и универзитет // Преводилац. - Бр. 4, св. 2 (1985), стр. 5-10.

6. Maksim Gorki (1868-1936) : ка Олимпу - пешице // Политика (31. октобар 
1986), стр. 11.

7. Од првог до најновијег Закона о универзитету : критички осврт на нови Закон у светлу српске културне традиције // Политика (3. октобар 1992), стр. 18.

8. Преглед историје словенске културе у осам томова : поводом међународног славистичког скупа у Украјини // Политика, културни додатак. - Бр. 33 (1992), стр. 13.

9. Успомена на професора Лалића : осврт на скуп одржан поводом двадесетогодишњице смрти професора Радована Лалића // Политика, културни додатак. - Бр. 31 (1992), стр. 13.

10. Пленарна седница Међународног славистичког комитета у Пјештанима // Зборник Матице српске за славистику. - Бр. 44-45 (1993), стр. 290.

11. Украјински писци о Десанки Максимовић // Политика, културни додатак. Бр. 2 (1993), стр. 15.

12. Велики песник Украјине : сто осамдесет година од рођења Тараса Шевченка // Политика, културни додатак. - Бр. 51 (1994), стр. 18.

13. Иван Франко : 1856-1916. : белешка о писцу уз превод песама // Књижевна реч (20. април 1994), стр. 13.

14. „Ког ће вам врага ти ћесари” : поводом сто осамдесете годишњице Тараса Шевченка // Књижевне новине (15. март 1994), стр. 6.

15. Научна конференција у Москви : „Југословенска књига у Русији и руска књига на Балкану" // Зборник за славистику Матице српске. - Бр. 46-47 (1994), стр. 313-314.

16. Нови статут Међународног славистичког комитета и припрема за XII међународни конгрес слависта // Зборник за славистику Матице српске. - Бр. 46-47 (1994), стр. 321-322.

17. Тринаести Конгрес славистичких друштава Југославије // Зборник за славистику Матице српске. - Бр. 46-47 (1994), стр. 311-312.

18. Душа у дволичном веку : поводом стогодишњице рођења Сергеја Јесењина // Политика, културни додатак. - Бр. 42 (11. новембар 1995), стр. 19.

19. Лекција за наредни век : разговор са новинаром „Дневника” Илијом Туцићем // Дневник. - Бр. 882 (28. јануар 1995), стр. 9.

20. Време срама : о начину доношења, садржини и почетним месецима примене српског Закона о универзитету из маја 1998. г. // Реч. - Бр. 51 (новембар 1998), стр. 105-120.

21. Два века од рођења Александра Пушкина : племенит, благ, лековит // Политика, култура-уметност-наука. - Бр. 48 (13. Март 1999).

22. Пушкин и српска култура // Пушкин и српска култура : поводом 200-годишњице Пушкиновог рођења : каталог. - Београд : Народна библиотека Србије, 1999. - Стр. 7-19.

23. Андреј Андрејевич Вознесенски, Виктор Борисович Кривуљин, Генадиј Николајевич Ајги, Едуард Венијаминович Лимонов, Јелена Шварц, Јуриј Михајлович Кублановски, Хенрих Венимијанович Сапгир : белешке о руским песницима // Крајина. - Бр. 4 (2002), стр. 28-32. 
24. Сергеј Јевгенјевич Бирјуков, Сергеј Маркович Гандлевски, Алексеј Максимович Паршчиков, Тимур Јурјевич Запојев, Василиј Анатољевич Филипов, Марија Глебовна Максимова, Олег Владимирович Јудајев (Глеб Цвељ), Андреј Корф, Руслан Маломагомедович Нурудинов, Андреј Генадијевич Пољаков, Вадим Калињин, Максим Албертович Амелин, Михаил Гронас, Дмитриј Владимирович Соколов, Станислав Зосимович Лакоба : белешке о руским песницима // Књижевни магазин. - Бр. 37-38 (2004), стр. 7-17.

25. Алес Разанав, Иван Јурјевич Голубничиј : белешка о савременим белоруским песницима // Писмо. - Бр. 82-83 (2005), стр. 251-252.

26. Лина Костенко, Васиљ Стус, Васиљ Холоборођко, Хрихориј Чубај, Јурко Позајак, Иван Малкович, Иван Лучук, Назар Гончар, Назар Федорук : кратке белешке о украјинским песницима // Писмо. - Бр. 82-83 (2005), стр. 293.

27. Максим Адољфович Замшев, Дмитриј Пригов, Николај Рубцов : белешка о савременим руским песницима // Писмо. - Бр. 82-83 (2005), стр. 251, 285-286.

28. Два украјинска песника : Олександр Ирванец, Володимир Цибуљко : реч на књижевној вечери украјинских песника гостију на београдским Међународним сусретима писаца // Развитак. - Бр. 225-226 (2006), стр. 42.

29. Просветни радник Јован Сибиновић из Кожеља : из необјављених записа његовог сина // Торлак. - Бр. 7 (2006), стр 21.

30. Станислав Красовицки : белешка о савременом руском песнику // Руски алманах. - Бр. 11 (2006), стр. 242.

31. Белешке о писцима // Антологија руске лирике : X-ХХІвек. - Београд : Паидеиа, 2007. - Т. I, стр. 276-302; т. II, стр. 259-288; т. III, стр. 281-327.

32. Педесет година књижевног рада Јована Јанићијевића // Преводилац. - Бр. $1 / 2$ (2007), стр. 84-87.

33. Рима Казакова : белешка о руској песникињи // Књижевне новине. - Бр. 1139 (2007), стр. 2.

34. Хиљаду година руске лирике : интервју // Политика. - Бр. 33795 (2007), стр. 19.

35. Два века Николаја Гогоља // Бдење. - Бр. 20 (2009), стр. 100-115.

36. Мирослав Топић : 1937-2012. // Филолошки преглед. - Бр. 39, св. 2 (2012), стр. 165

\section{Прикази и критика}

1. Један нови превод Љермонтовљеве поезије // Живи језици. - Год. III, бр. 3-4 (1961), стр. 203-205.

2. За ракете - против запрега : поводом издања Јевтушенкове збирке песама „Ракете и запреге” // Путеви. - Год. III, бр. 6 (1962), стр. 626-629.

3. С. Јесењин „Урвина” // Књижевне новине. - Бр. 179 (1962).

4. М. Горки, Историја књижевности // Гледишта. - Год. IV, бр. 1 (1963), стр. $117-118$.

5. Структура Јесењинове песничке слике // Гледишта. - Год. IV, бр. 2 (1963), стр. 51-69. 
6. Б. Бурсов, Национальное своеобразие русской литературы, МоскваЛенинград, 1964. // Филолошки преглед. - Год. III, св. 1-2 (1965), стр. 191-192.

7. Взаимосвязи и взаимодействие национальных литератур, Москва,1961. // Филолошки преглед. - Год. III, св.1-2 (1965), стр. 183-187.

8. Д. Шмелев, Слово и образ, Москва, 1964. // Филолошки преглед. - Год. III, св. 1-2(1965), стр. 192-193.

9. Л. Долгополов, Поэмы Блока и русская поэзия конца XIX- начала XX веков, Москва-Ленинград, 1964. // Филолошки преглед. - Год. III, св. 1-2 (1965), стр. 193-194.

10. Международные связи русской литературы, Москва-Ленинград, 1964. // Филолошки преглед. - Год. ІІІ, св. 1-2 (1965), стр. 191-192.

11. Новији совјетски радови о Јесењину и књига Ј. Прокушева „Юность Есенина" // Филолошки преглед. - Год. III, св. 1-2 (1965), стр. 191-192.

12. Допринос историји књижевности : осврт на књигу Сава Бабића, Како смо преводили Петефија, Нови Сад, 1985. // Политика. - Бр. 26208 (1986), стр. 12.

13. Слово о Игоровом походу // Политика (3. новембар 1986), стр. 11.

14. Књиге о превођењу : С. Бабић, Разабрати у плетиву; Б. Човић, Уметност превођења или занат // Политика (25. јун 1988), стр. 13.

15. Књига спонтане промишљености : поводом књиге Саве Бабића „Превесеји” // Руковет. - Бр. 4 (1990), стр. 1244-1247.

16. Београдски симпозијум „Руска емиграција у српској и другим словенским културама XX века" // Зборник Матице српске за славистику. - Бр. 53 (1997), стр. 317-318.

17. Јован Јанићијевић, Књижевни превод и преводна књижевност / у коауторству са С. Игњачевићем // Prevodilac. - Бр. 18, св. 3-4 (1999), стр. 46-52.

18. О континуитету отворености за културне контакте : Петар Буњак, Преглед пољско-српских књижевних веза, Београд, 1999. // Зборник Матице српске за књижевност и језик. - Бр. XLVII, св. 2-3 (1999), стр. 272-276.

19. Певана поезија : црна московска рода : књига Владимира Висоцког „Разговор с џелатом” у преводу Миливоја Баћовића // Политика, култура-уметност-наука. - Бр. 6 (14. април 1999), стр. 24.

20. Авангарда и традиција : старе и нове варнице : Виктор Соснора, Повратак мору, Београд, 2000. // Просветни преглед. - Бр. 2101 (2001), стр. 11.

21. Виктор Соснора, Победник и губитник : против књижевне проституције // Политика, култура-уметност-наука. - Бр. 5 (12. мај 2001), стр 11.

22. Противречне енергије у делу Достојевског : Милан Ранковић, Књижевно дело Достојевског, Београд : Ведес, 2001. // Књижевне новине. - Бр. 1046 (2001), стр. 20-21.

23. Озбиљан научни текст о књижевном стваралаштву Достојевског : поводом књиге Милана Ранковића, Књижевно стваралаштво Достојевског, Београд, 2001. // Савременик плус. - Бр. 99 (2002), стр. 55-58. 
24. Наши корени : Јеврем Дамњановић, Завичајна књига Тимочана и Крајинаца. Београд, 2006. // Развитак. - Бр. 223/224 (2006), стр. 141-142.

25. Људмила Поповић, Фокусна перспектива украјинске књижевности, Београд, 2007. // Зборник Матице српске за славистику. - Бр. 74 (2008), стр. 343-344.

26. Књига о фолклору и књижевном превођењу : М. Топић, П. Буњак, Фолклор и превод : огледи о рецепцији српског народног песништва у пољској књижевности. Београд, 2007. // Филолошки преглед. - Бр. 3 (2009), стр. $149-157$.

27. Медаљони о српској књижевности, универзитету и друштву : Васо Милинчевић, Универзитет и књижевност, Београд, 2013. // Књижевност и језик. - Год. 61, бр. 3/4 (2014), стр. 401-406.

\section{Преводи}

1. Ново путовање око света / О. Е. Коцебу. - Београд : Вук Караџић, 1965.

2. Одломци из поеме „Витез у тигровој кожи” / Ш. Руставели // Књижевне новине. - Бр. 285 (1966).

3. Сабрана дела I-V / С. Јесењин. - Београд : Народна књига, 1966.

4. Четири песме / Б. Пастернак // Књижевне новине. - Бр. 277 (1966), стр. 10.

5. Бездани огледала / Н. Заболоцки. - Београд : Култура, 1968.

6. Изабрана дела / М. Љермонтов. - Београд : Просвета, 1968.

7. Гвоздени сан / М. Љермонтов. - Београд : Култура, 1969.

8. Целокупна дела I-VI / С. Јесењин. - Београд : Рад, 1970.

(Издање је поновљено 1971, 1973, 1975, 1980, 1985).

9. Лирика / Б. Пастернак. - Београд : Рад, 1972.

10. Могао сам их позаборављати / Б. Пастернак // Мостови. - Бр. 10 (1972), стр. 109-114.

11. Сабрана дела, књ. 1, 2 / А. С. Пушкин ; приредио Милорад Павић. - Београд : Рад, 1972.

12. Гвоздени сан : Брајево писмо : лирске песме / М. Љермонтов. - Београд : Филип Вишњић, 1973.

13. Изабране песме / Е. Јевтушенко. - Београд : Рад, 1972.

14. Прстен живота / А. Блок. - Београд : БИГЗ, 1975.

15. Антологија руске поезије : XVII-XX век / избор Александра Петрова. Београд : Просвета, 1977.

(Г. Державин: Смрти кнеза Мешчерског, Река времена својим током; М. Љермонтов: Пехар живота, Једро, „Кад се заталаса пожутела њива”, Молитва, И мучно и тужно, „Пођем тако, сам сред пута тога”, „Не, не волим с тим жаром”, „Испод тајанствене и хладне полумаске”; Н. Њекрасов: Тројка, Размишљање пред свечаним улазом (одломак: „Покажите где је кућа таква”); Н. Мински: Град у даљини; Вјач. Иванов: Вага, Ноћна ружа, Пут у Емаус; И. Буњин: Сеоски просјак, Привиђење, 
Реч; М. Волошин: Крв; А. Бели: Отаџбина; А. Блок: Сутини, Фабрика, На пољу Куликовом, „На подвиге, врлине”, Русија, Дванаесторица $(1,12)$; С. Јесењин: „За дугом шумском пређом сивом”, „Певају кола отегнуто”, Јорданска голубица; Н. Заболоцки: Црвена Баварска, Лице коња, Бакрорез, Споредни канал)

16. Песме / В. Мајаковски, С. Јесењин, Е. Јевтушенко. - Београд : Нолит : Просвета : Завод за уџбенике и наставна средства, 1978.

17. Дела, књ. 1 / Борис Пастернак : приредио Света Лукић. - Београд : Слово љубве, 1979.

18. Панорама грузијске поезије XX века // Књижевне новине. - Бр. 571 (1979).

(Превод с руског дословног превода праћеног описом еуритмије и еуфоније оригинала лирских песама Галактиона Табидзеа, Мухрана Мачаваријанија, Шоте Нишнијанидзеа, Џасунга Чарквијанија и Гурама Патријашвилија)

19. Сабрана дела, књ. 1, 2 / М. Љермонтов. - Београд : Рад, 1980.

20. Песме / А. Блок. - Београд : Рад, 1982.

21. Песме и поеме / В. Мајаковски. - Београд : Рад, 1983.

22. Пољубац огњу / С. Јесењин ; избор и предговор Никола Бертолино. - Београд : Књижевне новине, 1984.

23. Свете мој древни / С. Јесењин ; избор и предговор Никола Бертолино, Мирослав Топић, Миодраг Сибиновић. - Београд : Књижевне новине, 1984.

24. Песме / J. Сајферт // Мостови. - Бр. 61 (1985), стр. 16-20.

(Говор гомиле, Грешни град, Стопут ништа, Дим од цигаре, Вечерња светла, Љубав, Филозофија, Лепеза, Песма, Вино авантуре)

25. Из савремене грузијске поезије // Савременик плус. - Бр. 3 (1989), стр. 192197.

(Превод лирских песама с дословног руског превода, снабдевеног описом еуфонијских и еуритмијских особина оригинала М. Лебанидзе, М. Квиливидзе, Лиа Стуруа и Б. Харанаули)

26. Витез у тигровој кожи / Ш. Руставели. - Београд : СКЗ, 1989.

(Превод стихова са дословног превода на руски, праћеног описом еуритмијских и еуфонијских особина старогрузијског оригинала)

27. Изабране песме / J. Бродски ; избор Миливоја Јовановића. - Београд : СКЗ, 1990.

28. Песме / Борис Христов // Српски књижевни гласник. - Бр. 4 (1992), стр. 34-35.

29. Песме / В. Хлебњиков // Савременик плус. - Бр. 1 (1992), стр. 46-47.

30. Песме / Иван Динков // Српски књижевни гласник. - Бр. 4 (1992), стр. 35-36.

31. Антологија белоруске поезије / приредио Иван Чарота. - Београд : СКЗ : Научна књига, 1993.

(Стихови Ф. Скарина, А. Римша, А. Филипович, С. Полоцки, П. Багрим, В. Сиракомља, В. Каратински, Ф. Багушевич, Ј. Лучина, Цјотка (Е. 
Пашкевич), J. Купала, J. Колас, К. Бујла, М. Багданович, А. Гарун, К. Свајак, Л. Родзевич, И. Канчевски (Хана Галубјанка), В. Жилка, В. Дубовка, М. Машара, Н. Арсењева, В. Хадика, П. Бровка, С. Дзаргај, Л. Генијуш, А. Астрејка. М. Танк (Јауген Скурко), А. Куљашов, П. Панчанка, А. Бјарозка, А. Писин, А. Салавеј (Алфред Радзјук-Кадњак), А. Барски, В. Караткевич, Н. Гилевич, А. Лојка, А. Вјарцински, Р. Барадулин, В. Зујонак, Г. Буравкин, Ј. Сипаков, А. Грачаников, Ј. Чиквин, Н. Артимович, А. Разанав, А. Сис)

32. Битка, (Где, кад) / А. Веденски // Српски књижевни гласник. - Бр. 2 (1993), стр. 97-102.

33. Естетика магијског у јужнословенској народној поезији / Б. Путилов // Савременик плус. - Бр. 9-11 (1993), стр. 16-23.

34. Звуци украјинске лире // Савременик плус. - Бр. 3-4 (1993), стр. 49-58.

(Украјински песници XX века: М. Семенко: Интерференција, Градски парк; М. Руденко: Лотос; И. Драч: Ждребе; М. Винграновски: „Хајдемо у врт. Да вам откријем"; Б. Олијник: Долазак (одломак из поеме); Х. Свитлична: Чернобиљске шуме; Б. Бојчук: „Захтевам сва своја права”; И. Малкович: „Сваког дана”; Н. Кирјан: Прокрустови срећници)

35. Српски фолклор у необјављеним рукописима Јурија Венелина / О. Микитенко // Савременик плус. - Бр. 9-11 (1993), стр. 12-16.

36. Украјинске поетске паралеле // Српски књижевни гласник. - Бр. 7-8 (1993), стр. 35-43.

(Анонимни писац с краја XVI века: Просјачка жалба Богу; Анонимни песник из прве половине XVII века: Чување од јереси; Анонимни песник из прве половине XVII века: О кнезу таме; Л. Баранович: Широм Украјине све саме руине, Без мира нема мира, Мач земљу резнув у крви огрезну; Иван Величковски: Минути свагда заједно, Ехо; Г. Сковорода: „Сваки град своје обележје носи”, „Аој, птиче жутобоко”; И. Драч: Крила (новогодишња бајка); В. Кордун: Славија (одломак из поеме), Негде је пала киша, Даљина пута)

37. Сонет, „Ништа не тајих пред тобом”, Сикстинска мадона, Од чега песма живи, Идеалисти, „Кад су сонете Данте и Петрарка”, „У сну ми долазиш ту" / Иван Франко // Књижевна реч (25. април 1994), стр. 13.

38. Из јерменске поезије, *** // Књижевне новине. - Бр. 915 (1995), стр. 4.

39. Јесен / Сергеј Јесењин // Књижевне новине. - Бр. 914 (1995), стр. 4.

40. Лењинград / Осип Мандељштам // Књижевне новине. - Бр. 913 (1. септембар1995), стр. 4.

41. Плавет века / С. Јесењин. - Београд : Interpress, 1995.

42. Поезија / Сергеј Јесењин. - Никшић : Унирекс, 1995.

43. Не, никад нисам био савременик ником / Осип Мандељштам // Савременик плус. - Бр. 28-39-40 (1996), стр. 5-14.

44. Александар Солжењицин : уметник, мислилац, пророк / Жорж Нива. Београд : Ново дело, 1999. 
45. Бајка о црном прстену / А. Ахматова // Књига. - Бр. 5 (1999), стр. 34.

46. Бронзани коњаник. Пир за време куге. Световна власт / А. Пушкин. - Београд : Ideia, 1999.

47. Два века Пушкина : песме и бајке. - Београд : Интерпрес, 1999.

48. Најезда Хавијера / Јуна Мориц // Клетва : Србија, пролеће 1999 : песме. Београд : Удружење књижевника Србије, 1999.

49. Песме и есеји / Осип Мандељштам. - Београд : Просвета, 1999.

50. Песме, поеме и есеји / А. Ахматова. - Београд : Рaideia, 1999.

51. Песме о љубави : Баћушков, Давидов, Пушкин, Веневитинов, Љермонтов, Њекрасов, Тјутчев, Фет, Ањенски, Блок, Хлебњиков, Јесењин, Гумиљов, Ахматова, Пастернак, Цветајева, Мандељштам, Заболоцки. - Београд : Паидеиа, 1999.

52. „По пустој земљи невољно поничући” / А. Ахматова // Политика, културауметност-наука. - Бр. 32 (1999), стр. 25.

53. Сабрана дела 1-5 / С. Јесењин. - Београд : VERZALpress, 2000.

54. Станце / Јуриј Кублановски // Овдје. - Год. 31, бр. 376/378 (2000), стр. 50.

55. Бајка о рибару и рибици. Бајка о попу и његовом раднику Балди. Бајка о златном петлићу // Бајка о рибару и рибици : бајке / А. Пушкин. - Београд : Драганић, 2001.

56. Људи месечеве светлости / Василиј Розанов. - Београд : Zepter Book World, 2001.

57. Песме о љубави : украјински песници. - Београд : Паидеиа, 2001.

58. Руске ноћи / В. Одојевски. - Београд : Паидеиа, 2001.

59. Тужни демон : песме / М. Љермонтов. - Београд : Просветни преглед, 2001.

60. Бронзани коњаник. Лирске песме // Цигани. Бронзани коњаник. Лирске песме / Александар Пушкин. - Београд : Завод за уџбенике и наставна средства, 2002.

61. Јерменска поезија // Рашка. - Бр. 38-39 (2002/2003), стр.6, 7, 9.

(Превод четири песме: Наири Зирјан: „Захвалан сам свету што те на свету има”, Хараконис; Вааган Давтјан: Цветање, Химна жени)

62. Руска поезија друге половине XX века // Крајина. - Бр. 4 (2002), стр. 13-27.

(Хенрих Сапгир: Парада идиота; Андреј Вознесенски: „Не треба ми много вичности", Гоја; Генадиј Ајги: И као бели лист, Шуморе брезе; Виктор Кривуљин: „Не тако радостан празник, но зато препун светом”, „Шта лицима лица говораху”; Едуард Лимонов: Шта још не можеш, „Све полете увис, и ветар задиже сукњу”; Јуриј Кублановски: Буђење; Јелена Шварц: Сметлиште)

63. У инат ветровима : антологија украјинске поезије XVI-XX век / приредила Људмила Поповић. - Бања Лука ; Српско Сарајево : Друштво српскоукрајинског пријатељства републике Српске : Завод за уџбенике и наставна средства Републике Српске, 2002.

(Герасим Смотрицки; Дамјан Наливајко; Из анонимних полемичких стихова 
80-90-тих година 16. века; Анонимне песме из Кијевско-михајловског зборника; Лазар Баранович; Иван Величковски; Данило Братковски; Феофан Прокопович; Григориј Сковорода; Иван Котљаревски; Левко Боровиковски; Амвросиј Метлински; Микола Костомаров; Маркијан Шашкевич; Олександар Афанасјев-Чужбински; Олександар Корсун; Виктор Забила; Тарас Шевченко; Степан Рудањски; Иван Франко; Павло Храбовски; Володимир Самијленко; Лесја Украјинка; Олександар Олесј; Микола Зеров; Павло Тичина; Клим Полишчук; Олекса Слисаренко; Јакив Савченко; Михајљ Семенко; Максим Риљски; Јевхен Малањук; Володимир Сосјура; Богдан Игор-Антонич; Микола Руденко; Богдан Бојчук; Дмитро Павличко; Лина Костенко; Богдан Рубчак; Борис Олијник; Васиљ Симоненко; Микола Винхрановски; Иван Драч; Петро Осадчук; Лидија Куљбак; Васиљ Стус; Марија Влад; Роман Лубкивски; Оксана Сенатович; Хана Чубач; Микола Воробјов; Данило Кононенко; Марија Павленко; Јуриј Завхородни; Васиљ Холобородјко; Віктор Кордун; Леонид Кисељов; Свитлана Жолоб; Михајло Шевченко; Наталка Никулина; Галина Паламарчук; Микола Лукив; Наталија Дзјубенко; Тарас Феђук; Надија Кирјан; Игор Римарук; Марија Матиос; Ирина Мироненко; Јуриј Андрухович; Иван Малкович; Васиљ Махно; Борис Шчавурски).

64. До виђења, друже мој, до виђења / С. Јесењин. - Подгорица : ЦИП, 2003.

65. Лилит / Михаил Гробман // Борба. - Бр. 275 (2003), стр. 16.

66. Песме / В. Кордун. - Градишка : Српско просвјетно и културно друштво Просвјета ; Бања Лука : Друштво српско-украјинског пријатељства Републике Српске, 2003.

67. Аутопортрет / Михаил Гробман // Стиг. - Бр. 92 (2004), стр. 61.

68. Видовито срце : руске народне песме и мисли. - Београд : Народна књига, 2004.

69. Лабуд, рак и штука / Сергеј Бирјуков; „Пио...” / Станислав Лакоба; Елегија, „Линч је то неочекиване зрелости” / Сергеј Гандлевски; Две шминкерке, Статуе, „Град фигав - само је” / Алексеј Паршчиков; Сликару Семјону Фабијасовичу / Тимур Запојев; „Ноћу” / Василиј Филипов; Из болничког дневника : „Тати и матери!”, „Леже и хрчу римски војници”, Надвисио је, Из свите сугласника: „Текло попут обезглављеног пледа”, „Преушила сурла слону” / Глеб Цвељ; „Не могу да ме убеде” / Марија Максимова; „Благост - то ти је кад фотку неког”, „Пешчани сат је хоризонтално”, „Киша, киша, киша, киша, киша” / Руслан Нурудинов; „Ја и кобац смо уз јамство” / Андреј Корф; „Севастопољ расточе, нејасно Керч”, Прво / Андреј Пољаков; „Временце с ноженцем тумара алејом” / Вадим Калињин; „К’о шипурак овештали ружичасти жбун““ / Максим Амелин; „Дом неуглађен свет није светао”, „Аха”, „Што нема пукотина у плоту” / Михаил Гронас; Море, „Ми ћемо, Леночка” / Дмитриј Соколов // Књижевни магазин (2004), стр. 7-17.

70. Под заклетвом : приче и изводи из писама / Антон Чехов. - Београд : Паидеиа, 2004. 
71. Склупчана магла / Михаил Гробман // Књижевне новине. - Бр. 1109-1110 (2004), стр. 32.

72. Кис / Татјана Толстој. - Београд : Геопоетика, 2005.

73. Левак : предање о тулском разроком леваку и челичној буви / Николај Љесков. - Београд : Интерпрес, 2005.

74. Лов у рајској долини / Алес Разанав; Песме / Максим Замшев; Стихови / Иван Голубничиј // Писмо. - Бр. 82-83 (2005), стр. 17-52.

75. Анђелица, „Моја неостварена врбо”, „Зрачити топлину у представи зима” / Володимир Цибуљко; Украјински песници; Роберт Фалкон Скот, Песме Источних Словена, Пејзаж с прозора касарне, Мој крст, Кратко писмо Олесји / Олександар Ирванец // Развитак. - Бр. 225-226 (2006), стр. 35-45.

(Одељак „Украјински песници” садржи: Володзимир Свидзински: „Данас киша лије”; Јакив Савченко: Христос отаву косио; Павло Тичина: Рат, „И Бели, и Блок, и Јесењин, и Кљујев”; Клим Полишчук: „Проклетог века струна одјекује"; Олекса Слисаренко: Суша; Михаил Семенко: Градски парк, Гаљини зуби, Интерференција; Максим Риљски: „Славим оног ко слободу воли”, „Уморих се од егзотике”, „Медове светле и златне купе”, „Да, пролог смо. Ви имате свога краља"; Јевхен Малањук: Август; Дмитро Фалкивски: „Полетели у боју кратком”; Степан Бен: Пољски сусрет; Лина Костенко: „Потражите цензора у себи”, Скитска жена; Васиљ Симоненко: Пророчанство 17. године; Иван Драч: Балада о удовиштву, Тајна почетка; Васиљ Стус: 97; Васиљ Холоборођко: Упркос болу, „Данас је нашао нешто", Стара кућа, Песма о мајци и њеној кћери, Без имена; Виктор Кордун: Безимена тишина, „И сама могућност”, Давни криптограми $(12,18,22)$; Григориј Чубај: Плач Јеремије, „Тако се крхка спушта”)

76. Девет украјинских песника // Писмо. - Год. 22, бр. 84-85 (2006), стр. 72-83.

(Лина Костенко: „Само сагради храм”, „Песник не може бити власништво”, „Мене, која се због корида на свет не јави”, „Дозиметром не може да се измери”; Васиљ Стус: „Још се славне стене поносите круне”; Васил Холоборођко: Упркос болу, Без имена; Григориј Чубај: Плач Јеремије, „Тако се крхка спушта”; Јурко Позајак: „Дотрчите код мене сутра”, Колекција песника № 7; Иван Малкович: Вече с прабабом, Бајка, Још једна јесен, С анђелом на рамену; Иван Лучук: Три кита, Миниуспаванка, Камењем затрпана реч, По, Усних коิ укопан, Легох под точак историје; Назар Гончар: Лирика футуристе; Назар Федорак: „Прошавши земљом твога тела”, „Ту стани и буди. И слушај плач огледала”, „Одлеђено жаром срце”, „Та со ме испија и оку мира не да̂”, Музика)

77. Кобзар / Тарас Шевченко. - Нови Сад : Савез Русина и Украјинаца Србије, 2006.

78. Моцарт и Салијери : „Мала трагедија” А. С. Пушкина ; превод либрета // Моцарт и Салијери : камерна опера Николаја Римског-Корсакова по истоименом тексту А. С. Пушкина. : програм. - Београд : Народно позориште, сцена „Раша Плаовић“, премијера 16. 04. 2006. - Стр. 7-11.

79. Песме / Дмитриј Пригов; Стихови / Николај Рубцов // Писмо. - Год. 22, бр. 
86-87 (2006), стр. 65-76; стр. 84-94.

80. Песме / Станислав Красовицки // Руски алманах. - Бр. 11 (2006), стр. 83-88.

81. „Прво ми натоварила”, Хтео је да буде човек, „Дала ми мајка срце” / Васил Холоборођко // Пролом. - Бр. 39 (2006), стр. 59-61.

82. Антологија руске лирике X-XXI век, том 1-3. - Београд : Паидеиа, 2007.

83. Из руског фолклора // Писмо. - Бр. 88-90 (2007), стр. 191-218.

84. Лирика / А. Кушнер. - Смедерево : Међународни фестивал поезије Смедеревска песничка јесен, 2007.

85. „Моја неостварена врбо” / Володимир Цибуљко // Књижевне новине. - Бр. 1138 (2007), стр. 6.

86. Неохлађени бисер / Михаил Бузник // Савременик плус. - Бр. 149/150/151 (2007), стр. 46-50.

87. Од чега песма живи?, „Ништа не тајих ја пред тобом”, Идеалисти, Модерне, Сикстинска мадона / Иван Франко // Траг. - Год. 3, књ. 3, св. 9 (март 2007), стр. 109-111.

88. „Опет, покретом несмелим” / Рима Казакова // Вечерње новости (21. фебруap 2007), стр. III.

89. Песме / В. Уфланд; Стихови / Д. Пригов // Руски алманах. - Бр. 12 (2007), стр. 51-56, стр. 105-108.

90. „Поезија је за тежаке”, „Волим да седим у диму крај ватре”, „Опет, покретом несмелим”, „Лета, дани!” / Рима Казакова; Анђелица / Володимир Цибуљко // Књижевне новине. - Бр. 1139 (2007), стр. 2; стр. 7.

91. Дани неизбежни / Михајљ Семенко; „Да, пролог смо” / Максим Риљски; „Носили ковчег” / Васиљ Чумак; Трава / Васиљ Мисик; Гледај у лица мртвих песника / Богдан Бојчук; „Потражите цензора у себи” / Лина Костенко; „Данас је нашао нешто” / Васиљ Холоборођко; „И сама могућност” / Виктор Кордун; „Тако се крхка спушта” / Григориј Чубај; „И Бели, и Блок” / Павло Тичина // Tisa. - Год. 1, бр. 1 (пролеће 2008), стр. 77-82.

92. Песме / Јуриј Одарченко // Руски алманах. - Год. 17, бр. 13 (2008), стр. 58-60.

93. Антологија Пушкин : изабране странице Александра Пушкина / избор, предговор, редакција и коментари Витомир Вулетић. - Нови Сад : Прометеј, 2009.

94. Бројанице од жада : авантуре Ераста Фандорина у XIX веку / Борис Акуњин. - Београд : Informatika, 2009.

95. Одабрана проза : приче и исписи / Николај Гогољ. - Београд : Завод за уџбенике, 2010.

96. Песме / Александар Блок // Писмо. - Год. 26, бр. 100 (2010), стр. 129-145.

97. Песме и поеме / Александар Пушкин ; избор и предговор Витомир Вулетић. - Нови Сад : Orpheus, 2010.

98. Песме и поеме / Михаил Љермонтов. - Нови Сад : Orpheus, 2010.

99. Предговор поеми Одмазда // Песме и поеме : избор / Александар Блок. - 
Нови Сад : Орфеус, 2010. - Стр. 284-292.

(Прештампано у: Поезија. - Год. 17, бр. 57/58 (2012), стр. 66-70)

100. Срби у Бахмутском срезу / С. И. Татаринов, Н. А. Тутова // Глас. - Год. 164 , књ. 15 (2010), стр. 213-221.

101. Изабране песме / Ана Ахматова. - Нови Сад : Orpheus, 2011.

102. Изабране песме / Николај Заболоцки. - Нови Сад : Orpheus, 2011.

103. Изабране песме / Осип Мандељштам ; избор Светислав Травица. - Нови Сад : Orpheus, 2011.

104. Антологија белоруске поезије / приредио Иван Чарота. - 2. проширено изд. - Београд : Српска књижевна задруга, 2012.

105. Русија, Ноћ, улица, фењер, апотека / Александар Блок // Поезија. - Год. 17, бр. 57/58 (2012), стр. 7-33.

106. Црни славуј : из савремене белоруске поезије // Књижевни магазин. - Год. 12, бр. 128/129 (2012), стр. 34-38.

(Алес Турович: „Снови постају светлост”, „Пролеће Лето Јесен”; Микола Вич: „Можда треба”; Аксана Спринчан: „Сунце - врхунце”; Алес Бадак: Песме; Едуард Акулин: Пољубац Јуде, Битка са собом; Виктар Шнип: Балада потопа; Микола Мјатлицки: „Пробиће се зрак”; Генадиј Пашков: Црни славуј; Јевгенија Јанишчиц: „Позови ме”, Како се зову сузе; Ригор Семашкевич: „Задатке да решавам”; Нина Мацјаш: Дани, као птице; Таиса Бондар: Модел; Владимир Каризна: Ноктурно; Максим Танк: Упитах човека)

107. Изабрана дела, том 1 / Антон Павлович Чехов ; приредио Зоран Божовић. - Сремски Карловци ; Нови Сад : Издавачка књижарница Зорана Стојановића, 2013.

108. Изабране приповетке / Антон Павлович Чехов ; приредио Зоран Божовић. - Београд : Завод за уџбенике, 2013.

109. Ноћу, Етида, Кијевска, Три сна о Кијеву, XX век, Птице / Лес Белеј // Rukovet. - Год. 59, бр. 1/4 (2013), стр. 80-81.

110. Изабрана дела / Михаил Јурјевич Љермонтов. - Сремски Карловци ; Нови Сад : Издавачка књижарница Зорана Стојановића, 2014.

111. Песме / Јекатерина Пољанска. - Београд : Српска књижевна задруга, 2014.

112. Караван : изабране песме / Новела Матвејева. - Москва : Вахазар ; Београд : Игам, 2015.

113. Лаки светови : приче / Татјана Толстој. - Београд : Геопоетика издаваштво, 2015.

114. Не куцај, глупаво срце : изабране песме / Сергеј Јесењин. - Москва : Вахазар ; Београд : Игам, 2015.

115. Шала : седам прича о љубави / Антон Чехов. - Београд : Paideia, 2015.

116. Витичасте заграде / Сергеј Носов. - Београд : Геопоетика издаваштво, 2016.

117. Песме Дмитрија Бикова // Савременик плус. - Бр. 249-250-251 (2016), стр. $18-38$.

(Песме: Нико већ неће да сече вене, Есхатолошка, Породична срећа, Све 
ми се сваљује из руку, Ка питању о улози детаља у структури прозе, Јутарње размишљање о божијем величанству, Кучкари ујутру изводе псе, Једанаеста заповест, Страшно је да живиш, страшно и да умреш, Тамо - нама ништа неће бити, Опет топљење, светлуцање, жубори, Жао ми је оних чија је младост пала, Нисам плакао док сам се хватао на обод полуслеђене рупе, Он ће сигурно доћи, Балада, Четврта балада, Пета балада, Девета балада, Црна река)

118. Тако и јесте / Андреј Базилевски. - Белград : Интерпрес, 2016.

119. Ти пролазиш на запад сунца : изабране песме / Марина Цветајева. - Москва : Вахазар ; Београд : Интерпрес, 2016.

120. Век мој, звер мој : изабране песме / Осип Мандељштам. - Москва : Вахазар ; Београд : Интерпрес, 2017.

121. Све што било је у души : изабране песме / Николај Заболоцки. - Москва : Вахазар ; Београд : Интерпрес, 2017.

122. Чисто небо : изабране песме / Леонид Мартинов. - Москва : Вахазар ; Београд : Интерпрес, 2017.

123. Dva veka zajedno : 1795-1995. Deo 2 / Aleksandar Solženjicin. - Novi Sad : Akademska knjiga ; Beograd : Paideia, 2018.

124. Песма последњег сусрета : изабране песме / Ана Ахматова. - Београд : Интерпрес ; Москва : Вахазар, 2018. - 167 стр.

125. Венац за Мандељштама : поезија, проза, есеји, преписка : руски и српски писци о Мандељштаму / приредио и предговор написао Миодраг Сибиновић. - Нови Сад ; Сремски Карловци : Издавачка књижарница Зорана Стојановића, 2019.

126. Изабрана дела / Александар Сергејевич Пушкин ; прир. Тања Поповић. - Сремски Карловци ; Нови Сад : Издавачка књижарница Зорана Стојановића, 2019.

127. Непожњевена трака : изабране песме / Николај Њекрасов. - Москва : Вахазар ; Београд : Интерпрес, 2019. 